\title{
UCRL-TR-210153
}

LAW RENCE LIVERMORE NATIO N A L LABORATORY

Single Cell Proteomics with Ultra-High Sensitivity Mass Spectrometry

M. Frank

March 2, 2005 
This document was prepared as an account of work sponsored by an agency of the United States Government. Neither the United States Government nor the University of California nor any of their employees, makes any warranty, express or implied, or assumes any legal liability or responsibility for the accuracy, completeness, or usefulness of any information, apparatus, product, or process disclosed, or represents that its use would not infringe privately owned rights. Reference herein to any specific commercial product, process, or service by trade name, trademark, manufacturer, or otherwise, does not necessarily constitute or imply its endorsement, recommendation, or favoring by the United States Government or the University of California. The views and opinions of authors expressed herein do not necessarily state or reflect those of the United States Government or the University of California, and shall not be used for advertising or product endorsement purposes.

This work was performed under the auspices of the U.S. Department of Energy by University of California, Lawrence Livermore National Laboratory under Contract W-7405-Eng-48. 


\section{Single Cell Proteomics with Ultra-High Sensitivity Mass Spectrometry}

LLNL ER LDRD project 02-ERD-002, Final report, February 14, 2005

Principal Investigator: Matthias Frank, PAT/M-Division

Co-Investigators: $\quad$ Abneesh Srivastava, PAT (postdoc)

Paul Steele, PAT (graduate student)

Eric Gard, C\&MS

Herb Tobias, C\&MS (postdoc)

David Fergenson, C\&MS (postdoc)

Joanne Horn, E\&ES

Maurice Pitesky, BBRP

Collaborators: $\quad$ Prof. Carlito Lebrilla, UC Davis

Scott Russell, UC Davis (graduate student)

Greg Czerwieniec, UC Davis (graduate student)

Laura Ludvigson, UC Berkeley (graduate student)

W. Henry Benner, LBNL (after 4/22/03 LLNL)

This work was performed under the auspices of the U. S. Department of Energy (DOE) by the University of California, Lawrence Livermore National Laboratory (LLNL) under Contract No. W-7405-Eng-48. The project (02-ERD-002) was funded by the Laboratory Directed Research and Development Program at LLNL. 
This project was a joint LDRD project between PAT, CMS and NAI with the objective to develop an instrument that analyzes the biochemical composition of single cells in realtime using bioaerosol mass spectrometry (BAMS) combined with advanced laser desorption and ionization techniques. Applications include both biological defense, fundamental cell biology and biomedical research.

BAMS analyzes the biochemical composition of single, micrometer-sized particles (such as bacterial cells or spores) that can be directly sampled from air or a suspension. BAMS is based on an earlier development of aerosol time of flight mass spectrometry (ATOFMS) by members of our collaboration [1,2]. Briefly, in ATOFMS and BAMS aerosol particles are sucked directly from the atmosphere into vacuum through a series of small orifices. As the particles approach the ion source region of the mass spectrometer, they cross and scatter light from two $\mathrm{CW}$ laser beams separated by a known distance. The timing of the two bursts of scattered light created by each "tracked" particle reveals the speed, location and size of the particle. This information then enables the firing of a highintensity laser such that the resulting laser pulse desorbs and ionizes molecules from the tracked particle just as it reaches the center of the ion source region. The full spectrum of ions is then measured using a time-of-flight mass spectrometer. The ability to rapidly analyze individual particles is clearly applicable to the rapid detection of aerosolized biological warfare agents so long as agent particles can be made to produce mass spectra that are distinct from the spectra of harmless background particles. The pattern of ions formed is determined by the properties of the laser pulse, the particle, and, in aerosol matrix-assisted laser desorption/ionization (MALDI), also the MALDI matrix used. As a result, it is critical that the properties of the laser pulses used for desorption and ionization be carefully chosen.

The work on this LDRD project was centered on demonstrating the usefulness of mass signatures obtained by BAMS for identification of biological agents and discrimination from background. To accomplish this goal this work also included a thorough study of the origins of the observed mass signatures (i.e. peak identification and dependence on bacterial growth conditions) and their dependence on laser parameters. Such a fundamental understanding of the mass signatures and their dependence on laser parameters is required for optimizing the desorption/ionization process and the bioaerosol mass spectrometer in order to increase the sensitivity and specificity of this method for practical CBNP applications.

Major technical achievements of this LDRD project include the following (references to publications containing more details are given where applicable).

1) the demonstration that unique mass signatures can be obtained from single bacterial spores and that those signatures are very different from many common "white powders" or hoax materials [3];

2) Species discrimination between some of the species within the genus of Bacillus [3]; 
3) An extensive study and explanation of the relationship between mass spectral reproducibility and laser parameters $[4,5]$;

4) Achieving improved mass spectral reproducibility using a flat-top laser $[5,6]$

5) Exploration of a 2-laser (IR/UV) desorption/ionization schem. This scheme was shown to be promising for increasing the ionization efficiency and providing more sprectral information. More work will be needed to fully utilize this technique;

6) Study and understanding of the influence of ion-chemistry in the laser desorption plume and the effect on mass spectral signatures [7];

7) Comprehensive identification of mass spectral markers (mostly metabolites with masses below $500 \mathrm{Da}$ ) using stable isotope labeling [8,9];

8) achieving a world-record sensitivity in aerosol MALDI-MS: 14 zeptomoles at 1 $\mathrm{kDa}[10]$.

In addition to the eight publications that resulted from this LDRD project, results from this work were presented at numerous international conferences and meetings.

This project resulted in several successful, high-visibility spin-offs, including

- Award of $\sim \$ 8 \mathrm{M}$ funding from DoD (TSWG and DARPA) for the development of high-throughput bioaerosol detection devices based on BAMS (Sept. 03-March 05)

- Award of $\sim \$ 400 \mathrm{k}$ from the Department of Homeland Security for new project end of FY04: enhanced bioaerosol detector. Project likely to continue through end of FY05.

- Award of $\sim \$ 500 \mathrm{k}$ from the Army for the analysis of explosive residues (Open burn open detonation project)

- Large interest from UC Davis researchers in collaborating on biomedical applications (no \$ yet)

There were only a few shortcomings of this project. There was limited success in obtaining high-mass (above kiloDaltons) protein signatures from single particles and cells. Also, while 2-laser desorption/ionization yielded some promising results the potential of this technique could not be fully utilized during this project. These shortcomings were due to the fact that the efforts were strongly focused on research and demonstrations for biodefense (please note that the project start date was right after September 11, 2001) and the more biomedical aspects were somewhat deemphasized. For the biodefense applications of single cell analysis lower mass metabolic markers work 
reasonably well. In addition, the BAMS system mass spectrometer used for this work was originally designed for a relatively low mass range and did not provide sufficient sensitivity at high mass. A redesign and optimization of this mass spectrometer for much higher mass was beyond the budget of this project. Future projects geared more towards biomedical analysis will require a higher mass range and funds will be sought to address this shortcoming in the future.

This project was a major success for LLNL and the LDRD program, in spite of the abovementioned few shortcomings. It made the BAMS collaboration at LLNL a major player in biodefense and created new infrastructure and knowledge for new research previously not possible. The objective to develop a rapid single cell analysis system for applications in national security and basic science was met.

References (all publications except 1 and 2 resulted directly from this LDRD project)

1. E.E. Gard, J.E. Mayer, B.D. Morrical, T. Dienes, D.P. Fergenson, K.A. Prather, Anal. Chem. 69, 4083-4091 (1997).

2. D.T. Suess, K.A. Prather, Chem. Rev. 99, 3007-3035 (1999).

3. "Instantaneous Reagentless Identification of Individual Bioaerosol Particles," D.P. Fergenson, M.E. Pitesky, H.J. Tobias, P.T. Steele, G.A. Czerwieniec, S.C. Russell, C.B. Lebrilla, J.M. Horn, K.R. Coffee, A. Srivastava, S.P. Pillai, M.P. Shih, H.L. Hall, A.J. Ramponi, J.T. Chang, R.G. Langlois, P.L. Estacio, R.T. Hadley, M. Frank and E.E. Gard, Anal. Chem. 76, 373-378 (2004) and UCRL-JC-151115-REV-1 (attached).

4. "Laser Power Dependence of Mass Signatures from Individual Bacterial Spores in Bioaerosol Mass Spectrometry,” P.T. Steele, H.J. Tobias, D.P. Fergenson, M.E. Pitesky, J.M. Horn, G.A. Czerwieniec, S.C. Russell, C.B. Lebrilla, E.E. Gard, and M. Frank, Anal. Chem. 75, 5480-5487 (2003) and UCRL-JC-153095 (attached).

5. “BioAerosol Mass Spectrometry: Reagentless Detection of Individual Airborne Spores and other Bioagent Particles Based on Laser Desorption/Ionization Mass Spectrometry, ' Paul T. Steele, Ph.D. thesis, UC Davis, June 2004. UCRL-TH-207560 (available upon request).

6. "Desorption/Ionization Fluence Thresholds and Improved Mass Spectral Consistency Measured Using a Flattop Laser Profile in the Bioaerosol Mass Spectrometry of Single Bacillus Endospores, ” P.T. Steele, A. Srivastava, M.E. Pitesky, D.P. Fergenson, H.J. Tobias, K.R. Coffee, E.E. Gard and M. Frank, submitted to Anal. Chem. Jan 2005 and UCRL-JRNL-208501-DRAFT (attached). 
7. "Toward Understanding the Ionization of Biomarkers from Micrometer Particles by Bioaerosol Mass Spectrometry,” S.C. Russell, G.A. Czerwieniec, C.B. Lebrilla, H.J. Tobias, D.P. Fergenson, P.T. Steele, M.E. Pitesky, J.M. Horn, M. Frank, and E.E. Gard, J. Am. Soc. Mass Spectrom. 15, 900-909 (2004) and UCRL-JP-200215 (attached).

8. "Stable Isotope Labeling of Entire Bacillus atrophaeus Spores and Vegetative Cells Using Bioaerosol Mass Spectrometry," G.A. Czerwieniec, S.C. Russell, H.J. Tobias, M.E. Pitesky, D.P. Fergenson, P. T. Steele, A. Srivastava, J.M. Horn, M. Frank, E.E. Gard, C.B. Lebrilla, Anal. Chem. 77, 1081-1087 (2005) and UCRL-JRNL-207205 (attached).

9. “Comprehensive Assignment of Mass Spectral Signatures from Individual Bacillus atrophaeus Spores in Matrix-Free Laser Desorption/Ionization Bioaerosol Mass Spectrometry, ” A. Srivastava, M.E. Pitesky, P.T. Steele, H.J. Tobias, D.P. Fergenson, J.M. Horn, S.C. Russell, G.A. Czerwieniec, C.B. Lebrilla, E.E. Gard and M. Frank, submitted to Anal. Chem. Nov. 2004 and UCRL-JRNL-207548-DRAFT (attached).

10. "Achieving high detection sensitivity (14 zeptomoles) of high-mass ions in Bio-aerosol mass spectrometry (BAMS),” S.C. Russell, G. Czerwieniec, C. Lebrilla, P. Steele, V. Riot, K. Coffee, M. Frank, and E.E. Gard, submitted to Anal. Chem. January 2005 and UCRL-JRNL-207606 (attached). 